\title{
PELATIHAN PEMANFAATAN BUMBU DAPUR SEBAGAI MINUMAN HERBAL MENUJU DI MASA PANDEMI COVID-19 TAHUN 2021
}

\author{
Yusmaniar, Adin Hakim Kurniawan, dan Surahman \\ Program Studi Farmasi, Poltekkes Kemenkes Jakarta 2, \\ E-mail: yusmaniar@poltekkesjkt2.ac.id
}

\begin{abstract}
ABSTRAK. Sebagian besar kalangan ibu rumah tangga masih minim mengenal beberapa jenis bumbu dapur sebagai obat tradisional yang memiliki kandungan zat aktif bersifat imunostimulan. Penduduk Pademangan Barat salah satu wilayah yang mempunyai kasus terbanyak COVID-19 di wilayah DKI Jakarta serta nilai kesehatan relatif rendah dibanding kelurahan lain. Kegiatan pengabdian masyarakat bertujuan memberikan pelatihan bumbu dapur sebagai obat tradisional dan menjadi alternatif minuman berbasis herbal instan dan sehat pada masa pandemi COVID-19. Metode yang digunakan adalah metode penyuluhan. Kegiatan pengabdian masyarakat oleh dosen dan mahasiswa Jurusan Farmasi Poltekkes Kemenkes Jakarta 2 meliputi pelatihan pengenalan bumbu dapur sebagai minuman herbal serta pengolahan serbuk jahe dan temulawak berkarbonasi sebagai alternatif minuman kesehatan. Hasil kegiatan dan pelatihan ini memberikan pengetahuan dan keterampilan mengenai pembuatan serbuk instan jahe dan temulawak berkarbonasi kepada mitra kelompok kader PKK, pengelola RPTRA serta warga kelurahan Pademangan Barat. Kegiatan pengadian masyarakat diharapkan meningkatkan derajat kesehatan dan perekonomian masyarakat di Kelurahan Pademangan Barat Jakarta Utara
\end{abstract}

Kata kunci: bumbu dapur; COVID-19; minuman herbal

\begin{abstract}
Most housewives are still minimally familiar with several types of kitchen spices as traditional medicines that contain active substances that are immunostimulants. The residents of West Pademangan are one area that has the most cases of covid 19 in the DKI Jakarta area and the health value is relatively low compared to other urban villages. Community service activities aim to provide training in kitchen spices as traditional medicines and to become an alternative to instant and healthy herbal-based drinks during the Covid 19 pandemic. The method used in counseling. Community service activities by lecturers and students of the Department of Pharmacy Poltekkes Kemenkes Jakarta 2 include training on introducing kitchen spices as herbal drinks and processing carbonated ginger and ginger powder as an alternative to health drinks. The results of this activity and training provided knowledge and skills regard manufacturing carbonated ginger and ginger instant powder to PKK cadre group partners, RPTRA managers, and residents of West Pademangan. Community service activities are expected to improve the health and economic status of the community in Pademangan Barat subdistric, North Jakarta.
\end{abstract}

Keywords: Herbal drink; seasoning spice; Covid 19

\section{PENDAHULUAN}

Coronavirus disease 2019 (COVID-19) merupakan penyakit yang disebabkan oleh turunan corona virus baru, yaitu virus yang terkait dengan keluarga virus yang mirip dengan severe acute respiratory syndrom (SARS) dan beberapa jenis virus flu biasa (Xiao \& Torok, 2020). Di Indonesia, pandemi virus COVID-19 masih terus meningkat dan selama Desember tahun 2020 sudah mencapai lebih dari lima belas ribu kasus. Jumlah kematian dilaporkan sebanyak 342 ribu kematian dengan case fatality rate (CFR) adalah 6,45\%. Jumlah kasus COVID-19 tertinggi terdapat di regional Amerika yang mencapai jumlah 2,3 juta kasus (WHO, 2020). Sementara itu, jumlah kasus di Indonesia telah meningkat secara signifikan menjadi 22.750 kasus yang dilaporkan pada bulan Mei 2020 dengan tingkat kematian mencapai 6,1\% (Kementerian Kesehatan RI., 2020). DKI Jakarta merupakan provinsi dengan jumlah kasus tertinggi yaitu mencapai 6,6 ribu kasus (Annisa, 2020).

Wilayah Jakarta Utara memiliki 485,590 rumah tangga dengan rata-rata terdapat empat anggota per rumah tangga (BPS Provinsi DKI Jakarta, 2020). Kepadatan penduduk di wilayah Pademangan Barat membawa implikasi terhadap tingginya masalah kesehatan. Data profil kesehatan tahun 2020, melaporkan bahwa kelurahan Pademangan merupakan salah satu wilayah yang mempunyai kasus terbanyak COVID-19 serta derajat kesehatan relatif rendah dibanding kelurahan lain. Sejak penyebaran virus COVID-19, banyak anjuran untuk mengubah pola perilaku masyarakat dalam melakukan upaya swamedikasi terutama masyarakat dapat melakukan kebiasan untuk mengkonsumsi herbal/jamu sebagai peningkatan sistem daya tahan tubuh (Anggraeni et al., 2021)beberapa peneliti dunia tengah melakukan studi potensi pengobatan tradisional untuk menjadi alternative penanganan COVID-19. Pemberitaan media online termasuk di Indonesia juga tidak sedikit yang memberitakan potensi obat tradisional dalam melawan COVID-19. Penelitian ini bertujuan untuk mengetahui pengobatan tradisional yang dapat digunakan sebagai peningkatan imunitas tubuh untuk melawan COVID- 19. Penelitian ini merupakan penelitian kualitatif analisis konten terhadap konten media online nasional yang berkaitan langsung 
dengan pemberitaan dan pengkajian tentang obat tradisional sebagai obat untuk meningkatkan kekebalan tubuh menghadapi wabah Covid-19 di Indonesia. Analisis data menerapkan teknik coding berbuka, yaitu proses analisis data yang dilakukan berdasarkan pada konsep abstrak yang kemudian dijadikan sebagai dasar pengklasifikasian data yang berkaitan dengan topik penelitian ini. Analisis koding berbuka menggunakan software Nvivo 12 plus melalui fitur auto code, crosstab, hirarchy chart, dan word frequency . Penelitian ini menemukan bahwa penggunaan herbal dapat meningkatkan fungsi kekebalan tubuh. Kekebalan tubuh yang optimal dapat mencegah tubuh dari infeksi COVID-19 (penyakit Coronavirus-19,

Masyarakat perkotaan pada umumnya dengan segala mobilitasnya dan pembangunan di berbagai tempat, kekurangan lahan untuk bercocok tanam sehingga jarang sekali untuk menanam obat di sekitar lingkungan rumahnya. Sehingga masyarakat lebih banyak mengkonsumsi herbal yang berasal dari bumbu dapur di pasar. Bahan bumbu dapur yang dimanfaatkan dirumah, salahsatunya adalah jahe dan kunyit (Peltzer \& Pengpid, 2018). Ibu rumah tangga mungkin sebagian besar sudah mengenal jahe, kunyit sebagai bumbu dapur dan herbal tradisional karena secara turun temurun dapat dimanfaatkan rimpang tersebut sebagai obat atau jamu, namun sebagian besar kalangan masyarakat banyak yang belum mengenal rimpang tersebut (jahe, kunyit, temulawak, dan lain-lain) sebagai herbal yang dapat dijadikan minuman yang sehat dan dapat memelihara daya tahan tubuh.

Masyarakat dan profesional kesehatan dapat berkomunikasi dan bekerja sama secara efektif untuk meningkatkan nilai preventif dan rehabilitatif kesehatan, Selain itu, tenaga kesehatan harus memiliki pengetahuan yang sangat baik dan berkontribusi terhadap masyarakat. Peningkatan pengetahuan tanaman herbal yang ada di kebun dan dijual di pasar bahkan sampai rumah tangga sebagai bumbu dapur, dapat menyembuhkan berbagai macam penyakit. Kalangan masyarakat dapat diberikan pengetahuan jamu dan tanaman obat tradisional melalui observasi langsung, seperti daun salam, sambiloto, kunyit, temulawak, jati belanda, cabe jawa, bawang merah, bawang putih, sereh dan lain-lain. Selain sembilan tanaman herbal atau obat tradisional tersebut, masih banyak tanaman lain yang mempunyai khasiat pencegahan dan penyembuhan (Purwitasari et al., 2021).

Pemanfaatan jahe sebagai bahan obat-obatan telah lama dikenal oleh bangsa-bangsa di kawasan asia. Dalam percobaan menggunakan hewan, terbukti bahwa ekstrak jahe merupakan stimulan bagi pernafasan dan jantung. Ekstrak jahe juga dapat memiliki khasiat sebagai pereda nyeri reumatik sendi, influenza, batuk, disentri bakteri dan radang. Ekstrak ini dapat diolah secara sederhana untuk menjadi sediaan obat, salah satunya dengan membuat produk serbuk effervescent instan. Dewasa ini berkembang pula produk-produk instan dari pangan yang digunakan untuk menjaga kesehatan salahsatunya adalah minuman instan serbuk jahe berkarbonasi. (Sitti Kholidah, Yuliet, 2014). Minuman yang berkarbonasi merupakan sediaan yang digunakan untuk membuat minuman ringan secara praktis. Kepraktisannya adalah sediaan dapat melarut sendiri dengan adanya gas $\mathrm{CO}_{2}$ yang membantu proses pelarutan (Helmalia et al., 2019), hal ini terlihat pada jenis kesukaan produk dan mempengaruhi psikologis konsumen. Disamping itu, sediaan effervesent menutupi rasa pahit sehingga menarik daya beli konsumen yang tidak suka mengkonsumsi jamu atau herbal (Ode Ikbal et al., 2019).

Pelatihan peningkatan pengetahuan herbal di wilayah ini dilakukan untuk menggalakan program back to nature, sehingga sasaran program pengabdian ini ditujukan kepada masyarakat, dalam hal ini diharapkan dapat memanfaatkan kelebihan jahe, kunyit dan temulawak sebagai komoditi unggul yang dapat menghasilkan nilai ekonomi tinggi yang tahan dalam penyimpanan dan praktis penggunaannya. Tujuan dari pengabdian masyarakat ini untuk memberikan pengetahuan tentang pemanfaatan bumbu dapur sebagai minuman herbal dan pelatihan pengolahan Jahe dan kunyit sebagai alternatif sediaan serbuk berkarbonasi dan minuman herbal. Berdasarkan hal diatas Tim Pengabdian masyarakat di Jurusan Farmasi Poltekkes Kemenkes Jakarta II ingin berpartisipasi dan berperan langsung dalam pemberdayaan masayarakat melalui kegiatan edukasi pemanfaatan bumbu dapur sebagai alternatif minuman herbal tradisional.

\section{METODE}

Kegiatan pengabdian mencakup bidang ilmu pengetahuan, teknologi dan seni (IPTEKS) yang diampu oleh dosen Jurusan Farmasi Poltekkes Kemenkes Jakarta II. Waktu pelaksanaan kegiatan, dilakukan pada bulan September tahun 2021 dilakukan di Wilayah Kelurahan Pademangan Barat, Kecamatan Pademangan Jakarta Utara dengan sasaran peserta yaitu pengurus ruang publik terpadu ramah anak (RPTRA) kelurahan, ibu kader PKK dan pengurus dasawisma serta tokoh masyarakat RT/RW.

Metode kegiatan mencakup penyuluhan tentang pemanfaatan bumbu dapur sebagai obat herbal dan pelatihan dengan cara praktek langsung membuat minuman serbuk instan berasal rimpang jahe dan temulawak berkarbonasi. Alasan memilih program 
tersebut karena dapat terbentuknya kelompok binaan yang memiliki pengetahuan dan keterampilan dalam proses pengolahan, formulasi dan fungsi pada pembuatan produk instan dari bahan alam (herbal). Sedangkan langkah-langkah kegiatannya terdiri dari proses persiapan,pelaksanaan, dan evaluasi kegiatan. Adapun kegiatan pelatihan sebagai berikut:

Tim pelaksana melakukan kerja sama dan perizinan kepada pihak aparat pemerintah DKI Jakarta khususnya pihak Kelurahan Pademangan. Tim pelaksana juga memiliki persetujuan dengan terlampirnya surat penerbitan SK pengabmas No HK.02.03/I/0096/2021. Selain perizinan dan kerjasama, pihak mitra mempersiapkan tempat pertemuan yang dilaksanakan di aula Kelurahan Pademangan Jakarta Utara dan menerima pengarahan dan sosialisasi rencana pelaksanaan kegiatan pengabdian masyarakat. Langkat selanjutnya adalah persiapan alat dan bahan yang diperlukan untuk pelaksanaan kegiatan pengabdian masyarakat, dan persiapan tempat untuk kegiatan pelatihan pemanfaatan bumbu dapur sebagai minuman herbal menuju ketahanan pangan di masa pandemi Covid 19 Pademangan Jakarta Utara tahun 2021 pada salah satu wilayah pengabmas kelurahan Pademangan Barat Jakarta Utara.

Tahap kedua merupakan pelaksanaan kegiatan pengabdianmasyarakat.Pesertakegiatanterdiridari Ibu kader PKK, ibu kader dasawisma, tokoh masyarakat RT/RW wilayah Pademangan Barat, Jakarta Utara, yang diikuti sebanyak 30 orang. Sedangkan tim pengabdian masyarakat dosen Poltekkes Kemenkes Jakarta II selaku presentator dan Undangan kegiatan dibuka oleh Ibu Lurah Pademangan Barat dan dihadiri pula oleh kasie kesra kelurahan penanggungjawab promkes penyakit tidak menular.

Tim pengabdian masyarakat terdiri dari 3 Dosen sebagai presentator dan 3 mahasiswa dari BEMJ Poltekkes Kemenkes Jakarta II selaku moderator dan enumerator kegiatan edukasi melalui zoom meeting. Tim penyuluh menyampaikan 3 materi inti pengetahuan tentang obat tradisional / herbal khususnya rimpang bumbu dapur melalui zoom meeting, adapun sesi materi sebagai berikut :

- Sesi pelatihan ke1: melakukan penyuluhan dengan tema pemanfaatan bumbu dapur pada obat tradisional di masa pandemi covid 19

- Sesi pelatihan ke 2: Demo membuat minuman sehat tradisional dari temulawak dengan teknologi minuman air berkarbonasi

- Sesi pelatihan ke-3 : Pelatihan Minuman Herbal Jahe instan dan temulawak karbonasi

Media ajar pengetahuan dalam kegiatan penyuluhan yaitu LCD/Handout dan video edukasi. Pada materi ini selama 40 menit serta 15 menit untuk sesi diskusi tanya jawab, total durasi waktu materi pertama selama 60 menit. Adapun materi penyampaian terdiri dari: pengertian dan manfaat obat tradisional dan upaya pengendalian dan pencegahan COVID-19 di masyarakat.

Pada Sesi ke 2 menyampaikan materi tentang Demo membuat minuman sehat tradisional dari temulawak dengan teknologi minuman air berkarbonasi. Metode pelaksanaan simulasi praktek melalui Aplikasi Virtual Meeting dengan durasi penyampaian@30 menit. Total durasi waktu pada materi ke 2 selama 60 menit. Adapun kebutuhan sampel atau bahan rimpang yang digunakan untuk metode pembuatan Jahe Instan dan temulawak modifikasi dengan bahan karbonasi sebagai berikut:

- $1 \mathrm{~kg}$ Jahe

- $1 \mathrm{Kg}$ Gula Pasir

- Air Matang

\section{Cara membuat :}

Jahe dibersihkan, dipotong kecil; Haluskan dengan blender menggunakan $500 \mathrm{ml}-1 \mathrm{~L}$ air; Saring dengan penyaring halus; Biarkan 30 menit untuk mengendapkan pati; Masak dengan api sedang hingga mendidih; Tambahkan gula aduk hingga gula mengental; Matikan api sambil terus diaduk hingga bentuk menjadi butiran halus; Saring dengan pengayak ; Simpan dalam kemasan tertutup.

Demo pembuatan temulawak modifikasi dengan bahan karbonasi sebagai berikut:

Temulawak Berkarbonasi

- 100 gram rimpang temulawak

- Gula putih /merah

- $100 \mathrm{ml}$ air

- $100 \mathrm{ml}$ minuman bersoda

- 2 irisan buah lemon secukupnya

- Es batu secukupnya

Cara membuat : Bersihkan rimpang dengan menggunakan air bersih; Tirsikan, rajang rimpang tersebut kecil-kecil; Blender hingga halus dengan air $500 \mathrm{ml}$; Saring, kemudian masak tambahkan 10 gram asam jawa dan gula Masak hingga mendidih dan kental. Saring, masukan dalam kemasan botol. Saran penyajian : Siapkan gelas, masukan 3 sendok sirup temulawak, tambahkan es dan masukan air soda sesuai selesa, berikan perasan jeruk nipis.

Pelatihan edukasi berupa penyampaian materi penyuluhan video demo praktek dengan virtual meeting dengan kriteria evaluasi sesuai dengan jadwal pre dan post test. Alat yang digunakan untuk melakukan evaluasi adalah menggunakan kuisioner yang dibuat dengan aplikasi Google Forms yang memuat evaluasi karakteristik responden, pengetahuan serta sikap dan tindakan perilaku. Tolak Ukur peserta mengikuti pengabdian 
masyarakat adalah adanya peningkatan pengetahuan dan keterampilan dalam melakukan penyuluhan dengan tema pemanfaatan bumbu dapur pada obat tradisional sebagai ketahanan Pangan di masa pandemi COVID-19 dan buat evaluasi jangka panjang berikutnya dapat memanfaatkan hasil produk minuman berupa serbuk jahe instan dan minuman temulawak berkarbonasi sebagai minuman sehat sehari-hari serta dapat menumbuhkan nilai kewirausahaan dikalangan ibu rumah tangga sehingga dapat tercipta ketahanan keluarga yang sehat, berekonomi dan sejahtera.

\section{HASIL DAN PEMBAHASAN}

Telah dilakukan kegiatan pengabdian kepada masyarakat berupa pelatihan pemanfaatan bumbu dapur sebagai minuman herbal menuju di masa pandemi COVID-19. Kegiatan dilaksanakan pada hari Sabtu, 04 September tahun 2021 di dua lokasi yaitu melalui virtual meeting dan aula kelurahan Pademangan Barat dengan memperhatikan protokol kesehatan $3 \mathrm{M}$ (memakai masker, menjaga jarak serta mencuci tangan). Kegiatan melibatkan dosen dan mahasiswa Jurusan Farmasi Poltekkes Kemenkes Jakarta 2 yang diikuti oleh 30 orang warga meliputi pengurus ruang publik terpadu ramah anak (RPTRA) kelurahan, ibu kader PKK dan pengurus dasawisma serta tokoh masyarakat RT/RW. Selain penyuluhan tentang pemanfaatan bumbu dapur, juga diberikan pelatihan tentang pembuatan serbuk instan jahe dan temulawak berkarbonasi sebagai minuman herbal yang berasal dari bumbu dapur yang sering dijumpai di rumah tangga.

Pemilihan lokasi kegiatan didasarkan pada hasil survey yang dilakukan sebelumnya dan diperoleh data bahwa kelurahan Pademangan merupakan salah satu wilayah yang mempunyai kasus terbanyak COVID-19. Kelurahan ini terletak di wilayah Jakarta Utara. Sebagian besar masyarakat mempunyai pekerjaan sebagai ibu rumah tangga sehingga dapat dijadikan mitra dalam kegiatan ini. dan Pademangan Jakarta Pusat.

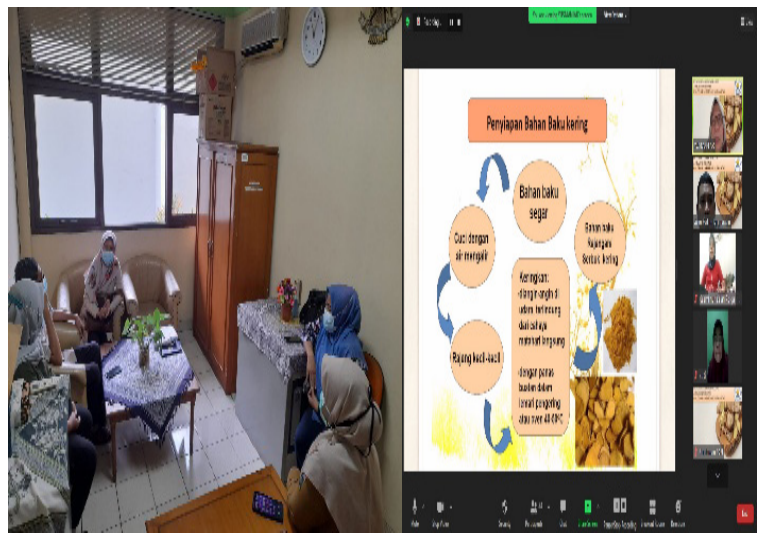

Gambar 1. Penyuluhan pemanfaatan bumbu dapur
Sebelum kegiatan ini dimulai peserta melakukan pengisisan kuisioner pre-test, kemudian kegiatan diawali dengan penyuluhan tentang pemanfaatan bumbu dapur sebagai tanaman herbal. Dalam kegiatan ini, masyarakat sangat antusias dalam menyimak materi yang diberikan. Selain pemberian materi dan diskusi, peserta kegiatan juga diberikan kesempatan untuk tanya jawab seputar pemanfaatan bumbu dapur sebagai tanaman herbal yang berada di lingkungan rumah tangga. Adapun hasil karakteristik sosiodemografi peserta terlihat pada tabel 1 berikut.

Tabel 1. Karakteristik Sosiodemografis

\begin{tabular}{|c|c|c|c|}
\hline No & Karakteristik Responden & $\begin{array}{l}\text { Jumlah } \\
\text { orang } \\
(\mathrm{n}=24)\end{array}$ & $\begin{array}{l}\text { Persentase } \\
\quad(\%)\end{array}$ \\
\hline \multirow[t]{3}{*}{1} & Jenis Kelamin & & \\
\hline & - Perempuan & 20 & 83,33 \\
\hline & - laki-laki & 4 & 16,67 \\
\hline \multirow[t]{4}{*}{2} & Usia & & \\
\hline & - 20-30 tahun & 5 & 20,83 \\
\hline & - 30-40 tahun & 5 & 20,83 \\
\hline & - $(>) 40$ tahun & 14 & 58,33 \\
\hline \multirow[t]{4}{*}{3} & Pendidikan Terakhir & & \\
\hline & - SD/SLTP & 2 & 8,33 \\
\hline & - SLTA & 18 & 75,00 \\
\hline & - Perguruan tinggi & 4 & 16,67 \\
\hline \multirow[t]{3}{*}{4} & Riwayat Penyakit degeneratif & & \\
\hline & - Tidak & 18 & 75,00 \\
\hline & - Ya & 6 & 25,00 \\
\hline \multirow[t]{4}{*}{5} & $\begin{array}{l}\text { Riwayat mengkonsumsi obat } \\
\text { tradisional }\end{array}$ & & \\
\hline & - Pernah, Sering & 14 & 58,33 \\
\hline & - Pernah, Jarang & 9 & 37,50 \\
\hline & - Tidak pernah & 1 & 4,20 \\
\hline \multirow[t]{7}{*}{6} & $\begin{array}{l}\text { Jenis bumbu dapur di rumah } \\
\text { yang sering dimanfaatkan sebagai } \\
\text { obat tradisional }\end{array}$ & & \\
\hline & - Kunyit & 14 & 30,43 \\
\hline & - Jahe & 13 & 28,26 \\
\hline & - Temulawak & 7 & 15,22 \\
\hline & - Sereh & 7 & 15,22 \\
\hline & - Kencur & 3 & 6,52 \\
\hline & - Lengkuas & 2 & 4,35 \\
\hline \multirow[t]{5}{*}{7} & $\begin{array}{l}\text { Bentuk sediaan yang sering } \\
\text { dimanfaatkan dalam membuat } \\
\text { obat tradisional }\end{array}$ & & \\
\hline & - Larutan/rebusan & 16 & 66,67 \\
\hline & - Bubuk kering & 6 & 25,00 \\
\hline & - Kapsul & 1 & 4,17 \\
\hline & - Pil & 1 & 4,17 \\
\hline \multirow[t]{7}{*}{8} & $\begin{array}{l}\text { Alasan memanfaatkan Khasiat } \\
\text { obat tradisional dalam kehidupan } \\
\text { sehari-hari pada pandemi Covid } \\
19\end{array}$ & & \\
\hline & $\begin{array}{l}\text { - Mengatasi flu/batuk dan } \\
\text { demam }\end{array}$ & 14 & 31,11 \\
\hline & $\begin{array}{l}\text { - Sebagai peningkat daya tahan } \\
\text { tubuh }\end{array}$ & 9 & 20,00 \\
\hline & - Mengatasi masuk angin & 7 & 15,56 \\
\hline & - Mengatasi diare & 9 & 20,00 \\
\hline & - Mengatasi DM & 4 & 8,89 \\
\hline & - Mengatasi hipertensi & 2 & 4,44 \\
\hline
\end{tabular}


Setelah mendapatkan materi, peserta kegiatan menyatakan bahwa selama ini hanya mengenal beberapa bumbu dapur yang dapat dijadikan obat tradisional, selain peserta lebih mengenal penggunaannya sebagai bahan tambahan dalam masakan. Peserta juga masih minim mendapatkan pengetahuan tentang kandungan zat aktif di masingmasing bahan bumbu dapur tersebut, misalnya jahe yang mengandung zat aktif Zingiberol, temulawak dan kunyit mengandung zat aktif kurkumin sehingga zat aktif tersebut berguna membantu proses penyembuhan bagi tubuh kita yang sedang sakit. Kegiatan ini dilanjutkan dengan pelatihan pembuatan produk instan jahe dan temulawak berkarbonasi. Hasil yang diperoleh berupa serbuk instan jahe dan temulawak berkarbonasi dibagikan kepada peserta pelatihan yang hadir, bahkan ada beberapa peserta yang mengkonsumsi produknya di tempat kegiatan dan menyatakan bahwa serbuk instan berkarbonasi tersebut tersebut rasanya enak, praktis, mudah dibuat dan memberikan efek sendawa dan hangat bagitubuh. Berdasarkan hasil kegiatan pengabmas tersebut, peserta pelatihan antusias untuk membuat sendiri di rumah masing-masing dan akan menjadikan agenda rutinitas pada acara kegiatan PKK dengan tujuan memberikan pengajaran terhadap ibu kader PKK dan dasawisma lainnya yang belum sempat hadir pada pelatihan tersebut. Adapun lembar evaluasi pembuatan minuman tradisonal dapat tersaji pada tabel 2.

Tabel 2. Pembuatan Produk Instan Jahe Dan Temulawak

\begin{tabular}{|c|c|c|c|c|c|c|c|c|c|}
\hline \multirow{2}{*}{ No } & \multirow{2}{*}{ Sikap } & \multicolumn{4}{|c|}{$\begin{array}{c}\text { Pre test } \\
\mathrm{n}=\text { orang }(\%)\end{array}$} & \multicolumn{4}{|c|}{$\begin{array}{c}\text { Post test } \\
\mathrm{n}=\text { orang }(\%)\end{array}$} \\
\hline & & $\begin{array}{l}\text { Sangat } \\
\text { setuju }\end{array}$ & Setuju & $\begin{array}{l}\text { Cukup } \\
\text { setuju }\end{array}$ & $\begin{array}{l}\text { Tidak } \\
\text { setuju }\end{array}$ & $\begin{array}{l}\text { Sangat } \\
\text { setuju }\end{array}$ & Setuju & Cukup & Sangat setuju \\
\hline 1 & $\begin{array}{l}\text { Pembuatan } \\
\text { produk instan } \\
\text { jahe karbonasi } \\
\text { memiliki } \\
\text { teknologi } \\
\text { sederhana di } \\
\text { kalangan rumah } \\
\text { tangga }\end{array}$ & $\begin{array}{c}0 \\
(0,0)\end{array}$ & $\begin{array}{c}18 \\
(75,0)\end{array}$ & $\begin{array}{c}6 \\
(25,0)\end{array}$ & $\begin{array}{c}0 \\
(0,0)\end{array}$ & $\begin{array}{c}12 \\
(50,00)\end{array}$ & $\begin{array}{c}12 \\
(50,00)\end{array}$ & $\begin{array}{c}0 \\
(0,0)\end{array}$ & $\begin{array}{c}0 \\
(0,0)\end{array}$ \\
\hline 2 & $\begin{array}{l}\text { Desain tampilan } \\
\text { label kemasan } \\
\text { produk jahe } \\
\text { dan temulawak } \\
\text { menarik }\end{array}$ & $\begin{array}{c}0 \\
(0,0)\end{array}$ & $\begin{array}{c}11 \\
(45,8)\end{array}$ & $\begin{array}{c}13 \\
(54,1)\end{array}$ & $\begin{array}{c}0 \\
(0,0)\end{array}$ & $\begin{array}{c}19 \\
(79,17)\end{array}$ & $\begin{array}{c}5 \\
(20,83)\end{array}$ & $\begin{array}{c}0 \\
(0,0)\end{array}$ & $\begin{array}{c}0 \\
(0,0)\end{array}$ \\
\hline 3 & $\begin{array}{l}\text { Bentuk, rasa } \\
\text { dan tektur jahe/ } \\
\text { temulawak instan } \\
\text { sangat menarik } \\
\text { dan disukai }\end{array}$ & $\begin{array}{c}0 \\
(0,0)\end{array}$ & $\begin{array}{c}11 \\
(45,8)\end{array}$ & $\begin{array}{c}13 \\
(54,1)\end{array}$ & $\begin{array}{c}0 \\
(0,0)\end{array}$ & $\begin{array}{c}19 \\
(79,17)\end{array}$ & $\begin{array}{c}5 \\
(20,83)\end{array}$ & $\begin{array}{c}0 \\
(0,0)\end{array}$ & $\begin{array}{c}0 \\
(0,0)\end{array}$ \\
\hline 4 & $\begin{array}{l}\text { Bahan dan Alat } \\
\text { pembuatan mahal } \\
\text { sebagai modal } \\
\text { usaha }\end{array}$ & $\begin{array}{c}13 \\
(54,17)\end{array}$ & $\begin{array}{c}7 \\
(29,1)\end{array}$ & $\begin{array}{c}4 \\
(16,66)\end{array}$ & $\begin{array}{c}0 \\
(0,0)\end{array}$ & $\begin{array}{c}0 \\
(0,0)\end{array}$ & $\begin{array}{c}2 \\
(8,33)\end{array}$ & $\begin{array}{c}4 \\
(16,67)\end{array}$ & $\begin{array}{c}18 \\
(75,00)\end{array}$ \\
\hline 5 & $\begin{array}{l}\text { Teknologi } \\
\text { pembuatan } \\
\text { minuman } \\
\text { temulawak } \\
\text { bersoda menarik }\end{array}$ & $\begin{array}{c}0 \\
(0,0)\end{array}$ & $\begin{array}{c}4 \\
(16,6)\end{array}$ & $\begin{array}{c}12 \\
(50,0)\end{array}$ & $\begin{array}{c}8 \\
(33,3)\end{array}$ & $\begin{array}{c}17 \\
(70.83)\end{array}$ & $\begin{array}{c}6 \\
(25,00)\end{array}$ & $\begin{array}{c}1 \\
(4,17)\end{array}$ & $\begin{array}{c}0 \\
(0,0)\end{array}$ \\
\hline 6 & $\begin{array}{l}\text { Alur proses } \\
\text { pembuatan, } \\
\text { mudah serta } \\
\text { hygenis }\end{array}$ & $\begin{array}{c}0 \\
(0,0)\end{array}$ & $\begin{array}{c}6 \\
(25,0)\end{array}$ & $16(66,6)$ & $\begin{array}{c}2 \\
(8,33)\end{array}$ & $\begin{array}{c}16 \\
(66,67)\end{array}$ & $\begin{array}{c}6 \\
(25,00)\end{array}$ & $\begin{array}{c}2 \\
(8,33)\end{array}$ & $\begin{array}{c}0 \\
(0,0)\end{array}$ \\
\hline
\end{tabular}

Tabel 3. Perubahan Penilaian pre-test dan post-test Pelatihan Pemanfaatan Bumbu Dapur Sebagai Minuman Herbal Menuju Di Masa Pandemi Covid-19

\begin{tabular}{|c|c|c|c|c|}
\hline \multirow{2}{*}{ No } & \multirow{2}{*}{ Unsur Materi Edukasi } & \multicolumn{2}{|c|}{ Nilai rata-rata } & \multirow{2}{*}{$\begin{array}{l}\text { Selisih rata-rata } \\
\text { penilaian }\end{array}$} \\
\hline & & pre-test & post-test & \\
\hline 1 & $\begin{array}{l}\text { Pemanfaatan bumbu dapur sebagai tanaman herbal } \\
\text { dikalangan keluarga }\end{array}$ & 68,75 & 93,50 & 24,75 \\
\hline 2 & $\begin{array}{l}\text { Pembuatan produk instan minuman kesehatan dari } \\
\text { Jahe dan temulawak berkarbonasi }\end{array}$ & 53,00 & 76,00 & 23,00 \\
\hline
\end{tabular}


Tahap akhir dilakukan dengan cara memberikan evaluasi kegiatan berupa pemberian soal post-test. Pemberian soal post test bertujuan memberikan evaluasi materi yang diajarkan pada kegiatan tersebut, apakah peserta sudah mengerti dan memahami mengenai materi yang diberikan. Materi yang diberikan terdiri dari 10 pertanyaan pengetahuan dan 6 pertanyaan sikap. Adapun hasil penilaian perubahan kondisi sebelum dan setelah program pelatihan terlihat pada tabel 3 .

Berdasarkan tabel 3, telah terjadi peningkatan pelatihan pemanfaatan bumbu dapur sebagai obat tradisional dan manfaat dalam peracikan obat tradisional sebagai peningkatan sistem imun tubuh dimasa pandemi Covid 19. Perbandingan hasil posttest dan pretest yang meningkat sebanyak $23 \%$ yaitu dari nilai rata-rata 53,0 pada pretest menjadi 76 pada saat post-test sehingga dapat dikatakan bahwa kegiatan ini dapat meningkatkan pengetahuan masyarakat mengenai pemahaman obat dan manfaat tradisional, macam-macam herbal bumbu dapur yang dapat digunakan untuk terapi alternatif peningkat sistem imun tubuh, cara mengolah obat tradisional tersebut dengan tepat, efek samping serta kontra indikasi dari setiap herbal yang terdapat pada bumbu dapur serta pemanfaatan jahe, kunyit dan temulawak sebagai pilihan utama bumbu dapur yang dapat dimanfaatkan sebagai imunostimulan pada masa pandemi COVID-19.

Hal ini sejalan dengan penelitian yang dilakukan oleh Yanuarti et al., 2020 tentang penyuluhan swamedikasi obat herbal di PKK Kecamatan dan Kabupaten Bojonegoro yang menunjukkan bahwa terjadi peningkatan edukasi pada peserta penyuluhan sebelum dan sesudah diberikan materi dengan peningkatan sebesa 92,02\% (Yanuarti et al., 2020). Adapun penelitian lainnya terdapat peningkatan nilai pengetahuan sebanyak $90 \%$ dengan nilai rata-rata sebesar 4,95 pada pretes tmenjadi 9,39 saat posttest (Erlianti et al., 2021). Penyuluhan kesehatan merupakan kegiatan pendidikan dapat dilakukan melalui penyebaran informasi-informasi pesan, menanamkan nilai keyakinan, sehingga warga masyarakat atau peserta pelatihan sadar, tahu dan mengerti, namun juga bisa dan mau melakukan anjuran yang memiliki hubungan dengan kesehatan serta terjadi peningkatan pengetahuan, keterampilan, dan sikap (Purwitasari et al., 2021).

Pemahaman peserta dalam pembuatan produk instan minuman kesehatan dari Jahe dan temulawak berkarbonasi memiliki perbandingan hasil post-test dan pretest yang meningkat sebanyak 24,75\% yaitu dari nilai rata-rata 68,75 pada pretest menjadi 93,50 pada saat post-test sehingga dapat dikatakan bahwa kegiatan ini dapat meningkatkan pemahaman dalam pembuatan jahe instan dan minuman temulawak berkarbonasi. Hal ini sejalan dengan pengabmas yang dilakukan oleh Retnowatil (2019) yang menujukan bahwa pelatihan produk jahe instan mendapatkan nilai yang positif sangat baik yang didapatkan bahwa 2 peserta dari 14 orang peserta pengabdian masih belum terbiasa menggunakan peralatan yang digunakan (Retnowati \& Retnowati, 2019). Adapun penelitian lainnya yang dilakukan oleh Citraningtyas G (2019) dari pelatihan pengabmas pembuatan obat tradisional terdapat peningkatan edukasi kelompok mitra berdasarkan manfaat pengobatan herbal dengan metode penyuluhan, sehingga berdasarkan banyaknya respon melalui diskusi aktif dari responden, serta terdapatnya produk jahe dan kunyit instan dengan hasil kreasi dan inovasi kelompok mitra (Citraningtyas et al., 2019).

Produk serbuk jahe instan yang dijadikan minuman tradisional berasal dari penyarian perasan lebih diminati dan memiliki sifat bahan kandungan yang tahan lama dibandingkan minuman dengan sediaan larutan tradisional seperti temulawak yang berkarbonasi. Hal ini disebabkan karena proses rajangan temulawak yang hanya dibuat larutan memiliki kadar air yang begitu besar sehingga dalam penyimpanan sediaan sangat terbatas dan mudah ditumbuhi oleh jamur. Jika berlangsung lama sediaan larutan hanya di batasi pada penyimpanan dengan kategori suhu dingin (lemari es) (Permata \& Sayuti, 2016). Determinasi fisik produk ekstrak bubuk jahe terdapat pada : suhu (pengapian), waktu pangadukan, kontinuitas sistem pengadukan dan kecpatan konstan, seluruh jenis ramuan dicampurkan mendidih. Proses pembuatan berjalan sesuai dengan cairan kental dan berbusa, kemudian perlunya pengapian masak dengan volume kecil dan sambil pengadukan sehingga terbentuk granul kering. Pengadukan bahan dan tingkat pemansan menjadi titik kritis dalam pembuatan serbuk jahe instan, dikarenakan pengapian dimatikan segera setelah terbentuk granul atau serbuk, jika tidak dimatikan, granul atau serbuk akan cepat meleleh kembali. Bentuk sediaan serbuk akan mengalami cracking berupa kepingan atau bongkahan maka granul atau serbuk dihaluskan dengan cara blender herbal selanjutnya dikerjakan dengan pengemasan menggunakan wadah plastik atau botol. Peserta pengabdian masyarakat mampu melakukan pembuatan produk granul atau serbuk instan setelah mencoba bebera trial produk.

Serbuk jahe instan dengan pengamatan organoleptis berbentuk granul atau serbuk, memiliki warna coklat muda, berbau aromatik jahe. temulawak dengan tekstur granul, warna kuning kecoklatan, berbau khas aromatik temulawak. Serbuk jahe instan dan temulawak berkarbonasi selanjutnya dikemas dalam wadah kemasan patch pot. Standar penyimpanan produk yang sesuai standar disimpan 
melalui temperatur kamar untuk serbuk jahe instan dan memakai kemasan wadah tanpa terjadi interaksi. Sedangkan minuman temulawak berkarbonasi (effervescent) disimpan dalam lemari pendingin es dan diminum dalam keadaan segar (Astriani et al., 2020).

Peserta pelatihan menyambut positif kegiatan pengabdian masyarakat yang dilaksanakan karena kegiatan tersebut baru pertama kali dilaksanakan di kelurahan Pademangan Barat dan menilai bahwa materi yang diperoleh dalam kegiatan ini sangat berguna dalam meningkatkan derajat kesehatan dan mempunyai potensi pengembangan untuk meningkatkanperekonomian. TimpesertaPengabmas belum melakukan percobaan tentang masa simpan produk serbuk instan jahe dan minuman temulawak berkarbonasi tersebut, dikarenakan produk ini belum akan dipasarkan ke masyarakat lainya dalam waktu dekat, karena dalam memasarkan produk harus melewati berbagai tahap pengujian dan proses perijinan dari pihak yang berwenang seperti Dinas Perdagangan, Bagian UMKM atau Dinas kesehatan melalui nomor registrasi PIRT.

\section{SIMPULAN}

Terdapat peningkatan pengetahuan peserta PKM atau kelompok mitra pengabmas mengenai pemanfaatan bumbu dapur sebagai obat tradisional dan manfaat dalam peracikan obat tradisional sebagai peningkatan sistem imun tubuh dimasa pandemi COVID-19. Hal ini dilihat dari antusiasme peserta dalam melakukan diskusi. Terdapat peningkatan keterampilan dalam pembuatan produk instan minuman kesehatan dari Jahe dan temulawak berkarbonasi, hal ini terlihat dari peningkatan nilai perilaku yang positif dari para peserta atau kelompok mitra. Penyuluhan dapat berlangsung aman dan tertib dan dilaksanakan yaitu pada saat penyuluhan dan demo pembuatan produk melalui edukasi dan penugasan peserta dalam membuat produk serbuk instan jahe dan minuman temulawak berkarbonasi di lingkuangan PKK.

\section{UCAPAN TERIMAKASIH}

Ucapan terima kasih kami sampaikan kepada Kementerian Kesehatan dan Kemenristekdikti atas fasilitas yang telah mendanai program pengabdian masyarakat (pengabmas), sehingga kegiatan ini dapat terselenggara dengan baik. Ucapan terima kasih pula kepada pihak Kelurahan Pademangan Barat, Kecamatan Pademangan Jakarta Utara, Tokoh Masyarakat RT/RW serta peserta pelatihan atas kontribusi aktif dalam kegiatan pengabdian masyarakat ini.

\section{DAFTAR PUSTAKA}

Anggraeni,A. D., Salahudin, S., Jamil, A. S., \& Rofida, S. (2021). Analisis Kualitatif Obat Tradisional Sebagai Agen Peningkatan Imunitas Tubuh Dalam Melawan Covid-19 Di Surat Kabar Online Indonesia. Jkm (Jurnal Kesehatan Masyarakat) Cendekia Utama, 8(2).

Annisa, D. (2020). Situasi Terkini Perkembangan Coronavirus Disease (Covid-19) 28 Mei 2020. Kementerian Kesehatan Ri.

Astriani, N. M. D. Y., Purwantara, I. K. G. T., \& Maryam, S. (2020). Pkm: Diversifikasi Produk Jamu Serbuk Instan Dari Herbal Usadha Bali Pada Kelompok Sari Pertiwi Desa Nyalian Kecamatan Banjarangkan. Jpai: Jurnal Perempuan Dan Anak Indonesia, 2(2), 1. Https://Doi.Org/10.35801/ Jpai.2.2.2020.30281

Citraningtyas, G., Wewengkang, D., \& Wiyono, W. (2019). Pkm Kelompok Pkk Dan Dasawisma Di Kelurahan Girian Weru Dua Kecamatan Girian Kota Bitung Melalui Pelatihan Dan Pembuatan Jahe Wangi Dan Kunyit Asam Instan Dari Tanaman Obat. Jurnal Lppm Bidang Sains Dan Teknologi, 5(1).

Erlianti, K., Ramadhani, J., Fadillah, A., Hasniah, H., \& ... (2021). Sosialisasi Pemanfaatan Herbal Bumbu Dapur Sebagai Antihipertensi Dan Pemeriksaan Tekanan Darah Di Desa Kandangan Baru Kecamatan Panyipatan Tanah .... Jurnal Abdidas.

Helmalia, A. W., Putrid, P., \& Dirpan, A. (2019). Potensi Rempah-Rempah Tradisional Sebagai Sumber Antioksidan Alami Untuk Bahan Baku Pangan Fungsional). Canrea Journal: Food Technology, Nutritions, And Culinary Journal, 26-31. Https://Doi.Org/10.20956/ Canrea.V2i1.113

Kementerian Kesehatan Ri. (2020). Situasi Terkini Perkembangan Coronavirus Disease.

Ode Ikbal, L., Asyik, N., Ilmu Dan Teknologi Pangan, J., Pertanian, F., \& Halu Oleo, U. (2019). Pengaruh Variasi Penambahan Serbuk Jahe Merah (Zingiber Officinale Var Rubrum) Dengan Variasi Penambahan Sukrosa Terhadap Karakteristik Fisik, Organoleptik Dan Aktivitas Antioksidan Serbuk Minuman Jahe Cokelat Instan. J. Sains Dan Teknologi Pangan, 4(2).

Peltzer, K., \& Pengpid, S. (2018). Prevalence And Determinants Of Traditional, Complementary And Alternative Medicine Provider Use 
Among Adults From 32 Countries. Chinese Journal Of Integrative Medicine, 24(8), 584 590. Https://Doi.Org/10.1007/S11655-0162748-Y

Permata, D. A., \& Sayuti, K. (2016). Pembuatan Minuman Serbuk Instan Dari Berbagai Bagian Tanaman Meniran (Phyllanthus Niruri). Jurnal Teknologi Pertanian Andalas, 20(1).

Purwitasari, N., Agil, M., \& Qurnianingsih, E. (2021). Meningkatkan Pengetahuan Masyarakat Dalam Menjaga Imunitas Dengan Obat Tradisional Di Era Normal Baru. Madaniya, 2(1), 20-28. Https://Doi. Org/10.53696/27214834.45

Retnowati,N.D., \& Retnowati,D.(2019).Pengolahan Dan Analisis Usaha Tanaman Jahe Menjadi Produk Jahe Instan Di Panti Asuhan Al-Ikhlas Ngentak Pelem Rt.13 Baturetno Banguntapan
Bantul. Kacanegara Jurnal Pengabdian Pada Masyarakat, 2(2). Https://Doi.Org/10.28989/ Kacanegara.V2i2.454

Sitti Kholidah, Yuliet, A. K. (2014). Formulasi Tablet Effervescent Jahe ( $\mathrm{Z}$ Officinale Roscoe) Dengan Variasi Konsentrasi Sumber Asam Dan Basa Effervescent. Online Jurnal Of Natural Science, 3(3).

Who. (2020). Therapeutics And Covid-19. Living Guideline. World Health Organization.

Xiao, Y., \& Torok, M. E. (2020). Taking The Right Measures To Control Covid-19. The Lancet Infectious Diseases, 20(5), 523-524. Https:// Doi.Org/10.1016/S1473-3099(20)30152-3

Yanuarti, T., Idealistiana, L., \& Anggraeni, N. (2020). Penyuluhan Swamedikasi Obat Herbal Di Pkk Kecamatan Pondokgede Kota Bekasi. Jurnal Antara Pengmas, 3(2). 